University of Michigan Law School

University of Michigan Law School Scholarship Repository

Articles

Faculty Scholarship

1906

\title{
Compelling the Production of Corporation Books and Papers
}

\author{
Edson R. Sunderland \\ University of Michigan Law School
}

Available at: https://repository.law.umich.edu/articles/1310

Follow this and additional works at: https://repository.law.umich.edu/articles

Part of the Evidence Commons, and the Fourth Amendment Commons

\section{Recommended Citation}

Sunderland, Edson R. "Compelling the Production of Corporation Books and Papers." Mich. L. Rev. 4 (1906): 635.

This Response or Comment is brought to you for free and open access by the Faculty Scholarship at University of Michigan Law School Scholarship Repository. It has been accepted for inclusion in Articles by an authorized administrator of University of Michigan Law School Scholarship Repository. For more information, please contact mlaw.repository@umich.edu. 
Compelling the Production of Corporation Books and Papers.-Hale, the plaintiff in the case of Hale v. Henkel, supra, was served with a subpoena duces tecum, commanding him to produce before the grand jury all contracts, memoranda, correspondence, reports, letters, etc., having to do with the business of the MacAndrews \& Forbes Company. He pleaded immunity from the operation of the subpoena under the 4 th amendment, which prohibits unreasonable searches and seizures. The Court held that an order for the production of books and papers may constitute an unreasonable search and seizure within the $4^{\text {th }}$ amendment. "While a search ordinarily implies a quest by an officer of the law, and a seizure contemplates a forcible dispossession of the owner, still, as was held in the Boyd Case [Boyd $v$. United States, II6 U. S. 616] the substance of the offense is the compulsory production of private papers, whether under a search warrant or a subpoena duces tecum, against which the person, be he individual or corporation, is entitled to protection. Applying the test of reasonableness to the present case, we think the subpoena duces tecum is far too sweeping in its terms to be regarded as reasonable. . . A general subpoena of this description is equally indefensible as a search warrant would be if couched in similar terms."

Mr. JUSTICE MCKENNA, in a concurring opinion, dissented from the opinion of the court in all these particulars, and not only declared the subpoena duces tecum sufficient and valid, but thought it so far removed in its nature from a search warrant that its use could not be deemed within the restrictive force of the $4^{\text {th }}$ Amendment. And he went so far as to hold that if the 5th Amendment did not apply to corporations, neither did the 4th Amendment apply to them. But no other member of the court agreed with him.

These three propositions summarize the holding of the Court: (I) A subpoena duces tecum must be as specific as a search warrant, (2) The $4^{\text {th }}$ Amendment applies to such a subpoena, and (3) A corporation may avail itself of the protection of the 4th Amendment as fully as may an individual.

E. R. S. 